\title{
Current Problems of Interstate Cooperation of Russian Federation for the Protection of Children in Case of Disputes between Parents Living in Different States
}

\author{
Aslan Khuseinovich Abashidze ${ }^{1}$, Denis Andreevich Gugunskiy ${ }^{1}$, Aleksandra Evgen'evna Koneva ${ }^{1}$, Mariya \\ Aleksandrovna Simonova ${ }^{1} \&$ Aleksandr Mikhailovich Solntsev ${ }^{1}$ \\ ${ }^{1}$ Peoples' Friendship University of Russia, Moscow, Russian Federation \\ Correspondence: Aslan Khuseinovich Abashidze, 6 Miklukho-Maklaya str., Moscow, Russian Federation.
}

Received: December 29, 2014 Accepted: March 27, 2015 Online Published: May 22, 2015

doi:10.5539/ass.v11n14p337 URL: http://dx.doi.org/10.5539/ass.v11n14p337

\begin{abstract}
In 2011 and 2013 the Russian Federation has become a State party to two important international treaties on the protection of human rights of children - Convention on the Civil Aspects of International Child Abduction of 1980 and Hague Child Protection Convention of 1996. Considering the social significance of these conventions, there is a practical need in the elaboration of the procedure of their application by the state organs as well as the organisation of knowledge-raising campaign aimed at disseminating the information on the provisions of the conventions among the population of the Russian Federation.
\end{abstract}

Keywords: human rights, children rights, international law, convention, responsibility of parents

\section{Introduction}

Ensuring the right of the child who is taken away from one or both parents to maintain personal relations and direct contact with both parents on a regular basis as well as guaranteeing the rights of custody and access to a child exercised by parents in cases when they are separated and are living in different States, is one of the most challenging international legal and national legal issues in the area of child protection.

Due to a considerable growth in the number of cases of illegal removal of children out of the national territory of the Russian Federation, or their non-return to the Russian Federation, as well as the failure of a parent living outside Russia to provide access to communicate with the child and participate in his/her upbringing for the other parent living in the Russian Federation, there is an urgent need to find effective ways to protect children from the negative effects of the illicit removal and retention and to take necessary steps to prevent the onset of such cases (Solntsev \& Koneva, 2013; Archard, 2004; Raymond, 2007; Fenton-Glynn, 2014). Indeed, according to the Ministry of Justice of the Russian Federation, the number of marriages of Russian citizens to foreigners is growing steadily. For example, in 2006, the number of marriages between Russians and the French amounted to 108 , and in 2008, this number rose to 130; in 2006, the number of marriages with the citizens of Israel amounted to 219 , and in 2008, it rose to 263. From 2006 to 2008, 939 marriages were contracted with the US nationals, and the number of marriages contracted with Germans peaked at 2564. Dramatic cases of Irina Bergset (Note 1), Rimma Salonen (Note 2), Irina Belenkaya (Note 3) and many other women, citizens of Russia, also prove the relevance of the topic researched.

\section{Method}

The article applied scientific methodological approach which allows to determine the scope of the research, clarify the basic concepts and categories, highlight the key conceptual aspects of the research topic. The study used scientific methods of cognition, such as dialectics, analysis and synthesis, the method of generalization, system-structural method. The authors also widely used special methods of science: legal and technical, historical, method of forecasting.

The task of a comprehensive analysis of the research topic has necessitated the use of the comparative method of research implementation processes in various states, which was dictated by the need for a scientific understanding of the issues and trends in the protection of children's rights. 


\subsection{Legal Analysis}

The Hague Convention on the Civil Aspects of International Child Abduction of October 25, 1980 (hereinafter the 1980 Convention), is an effective international legal instrument for resolving disputes related to the wrongful removal or retention of children. Accession to this international legal instrument allows member- States to provide at the international level additional guarantees of the rights of children and their parents (or other legal representatives), to create a legal mechanism of interaction with other States in dealing with the issue of prompt return of children wrongfully removed or retained in foreign countries, and to take effective measures to make sure that rights of custody and of access provided by the legislation of a Contracting State, are effectively respected in the other States (Abashidze et al., 2014; Eekelaar, 1986; Guggenheim, 2005).

For reference, it should be mentioned that the Russian Federation is a party to the 1980 Convention, in accordance with the Federal Law No. 102-FZ of May 31, 2011, with the Convention entering into force in Russia on October 1, 2011. Under Art. 38 of the 1980 Convention "the accession will have effect only as regards the relations between the acceding State and such Contracting States as will have declared their acceptance of the accession. Such a declaration will also have to be made by any Member State ratifying, accepting or approving the Convention after an accession ..." (Convention on the Civil Aspects of International Child Abduction of 1980 URL: http://www.hcch.net/index_en.php?act=conventions.text\&cid=24).

So far, the 1980 Convention has been ratified by 93 States, but for the time being, only 35 States recognized the Russian Federation, including 13 Member States of the European Union (EU) (Note 4) and 22 other States (Note 5). Russia, in its turn, recognized the accession of the Republic of Korea (entered into force on 01.10.2013). Thus, under the 1980 Convention, Russia has treaty relations with 36 States. It should further be noted that 15 EU Member States have not yet recognized Russia under the Convention. By the way the USA also have not recognized Russia under the Convention (Fass, 1997). Bearing in mind that legal issues relating to the Convention are resolved uniformly in all EU Member States pursuant to the provisions of Council Regulation (EC) No. 2201 of November 27, 2003 "On the jurisdiction and the recognition and enforcement of judgments in matrimonial matters and the matters of parental responsibility" (Council Regulation (EC) No 2201/2003 of 27 November 2003 concerning jurisdiction and the recognition and enforcement of judgments in matrimonial matters and the matters of parental responsibility. URL: http://eur-lex.europa.eu/LexUriServ/LexUriServ. do? uri=CELEX:32003R2201:EN:HTML) and considering that the Convention is already in force between Russia and 13 EU Member States, it seems that the reference of the other 15 EU Member States to the fact that the Russian legislation contradicts the legal standards applicable on their respective territories as a basis of their refusal to recognise Russia under the 1980 Convention is not valid. Therefore, the non-recognition of Russia by these countries is hardly motivated by legal reasons rather by political ones. Such a behavior blocks the creation of the only legal framework of EU cooperation with the Russian Federation in cases of child abduction which is in a clear contradiction with the principle of ensuring the best interests of the child and thus undermines the protection of children's rights on their territories (Skakun, 2014; Archard \& Skivenes, 2010; Forst \& Blomquist, 1992; Zermatten, 2010).

Another international legal instrument specifically designed for the efficient resolution of disputes on child-rearing between parents who are citizens of, or reside in different States, is the Convention "On Jurisdiction, Applicable Law, Recognition, Enforcement and Cooperation in respect of Parental Responsibility and Measures for protection of children's rights " of October 19, 1996 (hereinafter - the Convention of 1996). This convention has been in force in the territory of the Russian Federation since June 1, 2013.

An appropriate central authority (hereinafter - the Central Authority) will be established in the State party in order to coordinate the implementation of the above-named Conventions. Ministry of Education and Science is a Central Authority, in charge of the implementation of these two conventions in the Russian Federation. (Schepetkova, 2014).

In this regard, it is important to point out that the majority of States Parties to the 1980 and 1996 Conventions assign the Ministry of Justice as the Central Authority. However, the choice of the Russian Federation is based on the fact that, since the Conventions are aimed at protecting the rights and interests of the child, the Central Authority's functions should be concentrated in the hands of a public authority, which is a key state institution for the protection of children's rights; namely, the Russian Ministry of Education and Scienc (King \& Piper, 1995; Archard \& Macleod, 2002).

\section{Results}

It should further be noted that the implementation of the Conventions of 1980 and 1996 at the national level poses a challenge and requires changes to be made to a number of national acts in order to harmonize the 
national legislation of the States Parties with the international treaties provisions (Jones and Walker, 2011). Pursuant to the provisions of para. 4 of Art. 15 of the Constitution of the Russian Federation of 1993 (The Constitution of the Russian Federation. URL: http://www.constitution.ru/en/10003000-01.htm), the 1980 and 1996 Conventions form an integral part of the legal system in Russia. Accordingly, if they establish other rules than those stipulated by the Russian legislation, the provisions of these Conventions would apply.

Given the social importance of the treaties and the need for their effective application in the territory of the Russian Federation, it is necessary to develop comprehensive guidelines explaining the procedure for applying the provisions of the Conventions of 1980 and 1996 by the authorities at all levels, as well as to analyze and take into consideration the experience of their implementation in foreign States. To that end, the Federal Act No. 126-FZ of May 5, 2014 "On amendments to a number of legislative acts of the Russian Federation in connection with the accession of the Russian Federation to the Convention on the Civil Aspects of International Child Abduction" was adopted. The afore-referred Act amended the following four laws: the Law of the Russian Federation No. 2487-I "On Private Detective and Security Activity in the Russian Federation" of March 11, 1992; Family Code of the Russian Federation; The Federal Law On Bailiffs No. 118-FZ of July 21, 1997; Code of Civil Procedure of the Russian Federation (CCP of the RF); Federal Law "On Enforcement Proceedings" of October 2, 2007 No. 229-FZ.

One of the significant changes in the procedure for implementing the 1980 Convention in the territory of Russia is the following: before the effective date of the amendments, the Ministry of Education and Science upon receipt of an application for return of the child or for the exercise of the right of getting an access to the child (subject to the conformity of the application to the norms of the 1980 Convention) used to send the corresponding request for locating the child, and receiving information concerning the conditions of the child's life and upbringing, etc. to Russian regional bodies of trusteeship and guardianship. Under the new law, the Ministry of Education and Science since May 16, 2014 is to send tracing requests for the abducted or returned child to the structural subdivisions of the bailiffs of the territorial bodies of the Federal Bailiff Service.

Designation of courts (one in each Federal district), which will be engaged in the consideration of requests for the return of the child or the implementation of the rights of access to a child on the basis of an international treaty to which the Russian Federation is a Member State, has become another important novelty (Tobin, 2009). Designated Courts of justice are the following: in Central Federal District - Tver District Court of Moscow ; in Northwestern Federal District - Dzerzhinsky District Court of St. Petersburg; in Southern Federal District Pervomajskij District Court in Rostov-on-Don; in The North Caucasus Federal District - Pyatigorsk city court; in Volga Federal District - Kanavinskiy District Court of Nizhny Novgorod; in Urals Federal District the District Court in Yekaterinburg; in Siberian Federal District - Central District Court of Novosibirsk; in Far Eastern Federal District - the Central District Court of Khabarovsk). Designated courts in the Republic of Crimea and Sevastopol will be determined later (Note 6).

However, as far as the application of the 1980 Convention in the territory of the Russian Federation is concerned, it seems appropriate to give examples of the current practice of foreign countries relative to the implementation of the Convention in respect of the designation of competent authorities (courts), empowered to deal with the case of the return of the children and the exercise of rights of access. It is to be recalled that at the present time 8 courts consider such cases in the Russian Federation. In contrast to this approach, examples of the Czech Republic and Japan can be mentioned. In these countries the cases related to the return of children and implementation of access rights are divided into two different categories and are to be considered by different groups of courts. For example, in the Czech Republic the City Court in Brno (Court of the First Instance) and the Regional Court in Brno (Court of Appeal) are entitled to take decisions on the return of children. As for the exercise of the right of access to the child, 86 courts of first instance and 8 courts of appeal have jurisdiction to consider submitted applications. In Japan, two courts have jurisdiction over the cases of return of children (the Family Court of the city of Osaka and the Family Court of the City of Tokyo), and courts which have jurisdiction to determine the place of residence of the child are competent to consider applications for the exercise of the right of access. As we see, States choose different approaches to designate Competent Authorities (courts), empowered to deal with the case of the return of children and the exercise of rights of access. The first approach suggests separation of cases regarding the return of children and cases regarding the exercise of rights of access into two different categories within the jurisdiction of different competent authorities (courts). The second approach suggests integration of these two types of cases into one category, to be considered by the same courts. As one can see, the Russian Federation has opted for the second approach which is most likely due to the common features of disputes arising between parents living in different States and related to the wrongful removal or retention of children (Fellmeth, 2002; Pardeck, 2006). 
The fact that the legislative changes are aimed at ensuring a prompt settlement of children's removal disputes by the competent Russian authorities, can be seen as considerable progress. Specifically, in accordance with para. 6, Art. 65 of the Federal Law "On Enforcement Proceedings" No. 229-FZ of October 2, 2007, the bailiff shall make a ruling within 24 hours from the date of submission of the request, ordering a retrieval or renouncing of a retrieval of the child on the basis of a tracing request obtained from the Russian Ministry of Education and Science. Moreover, in accordance with Art. 244.15 of the Code of Civil Procedure (CCP) of the Russian Federation, an application for the return of the child or of the exercise of rights of access is considered by a competent court within a period not exceeding forty-two days from the date of the acceptance of the application by the court (Note 7). By the terms of Art. 244.19 of the CCP , copies of judicial decisions concerning cases of the return of the child or of the exercise of the right of access shall be forwarded not later than the day following the date of court's ruling, to the Ministry of Education and Science of the Russian Federation, as well as to the court that had been considering the case involving the dispute over the child in question, if the court that issued the ruling is familiar with this case.

In respect of the 1996 Convention it should be noted that (according to its preamble) it was adopted with the aim of improving the protection of children in international cases by avoiding contradictions between the legal systems of the States Parties in respect of jurisdiction, applicable law, recognition and enforcement of measures to protect children. Currently a legislation on implementing rules of the 1996 Convention in the Russian Federation is under development. However, the possibility to recognize and execute foreign judgments under the can now be materialized. In accordance with the provisions of Art. 409 of the CCP, the decisions of foreign courts, including friendly settlement agreements, are recognized and enforced in the Russian Federation, if stipulated in an international treaty of the Russian Federation. The procedure for recognition and enforcement is determined by the current Russian civil procedural legislation. Article 23 of the Convention among the reasons preventing the fulfillment and recognition of a foreign judgment, provides as follows: if the measure, except in urgent cases, was adopted in the context of judicial or administrative proceeding, without giving the child the opportunity to be heard, in violation of core procedural principles of the requested State.

In Russian legislation, the fundamental procedural principles, nonobservance of which violates the procedural equality of the parties and, therefore, prevents the execution and recognition of a foreign court's judgment, are enshrined in Art. 412 of the Code of Civil Procedure.

As the central body responsible for the implementation of the Convention, The Ministry of Education and Science carries out actions, which are similar to those that it takes with regard to the 1980 Convention.

It should be noted that a decision on the recognition of foreign court rulings concerning family relations and the return of children to one parent was made for the first time in the Russian judicial practice on September 11, 2013 when the Moscow City Court ordered a Russian citizen who had an American wife (US citizen) and who had removed their children to Russia, to return them to their mother - his ex-wife.

The story runs as follows: the wife accused her spouse of domestic violence and filed for divorce which was granted in 2011. The two minor sons have dual citizenship - US and Russian - while the younger son has German citizenship. Both children were born in Switzerland and in January 2011, the family moved to London (Egorov, 2013). The English court decided to leave the children with their mother during the divorce proceedings. Sometime later the children left the UK for Russia on vacation with their father and did not come back to their mother. The latter requested to return the children to her. Her husband received the British court's injunction concerning the obligation to return the children. His ex-wife came to Russia twice - in winter and in summer - with the injunction and asked her spouse to return the children. But he was in no hurry to carry out the decision of the British Court. As a result, the American mother filed a lawsuit to the Moscow City Court demanding the recognition and enforcement of foreign court decisions. In her claim she referred to the 1996 Convention. The Moscow City Court, taking into consideration the decision of the Supreme Court of England and Wales and referring to the 1996 Convention ruled on the execution of judgments of the Court of England in the territory of the Russian Federation and, therefore, ordered the father - a citizen of Russia, to return the children to their mother.

\section{Discussion}

The analysis conducted in the present article reveled that Russia is moving steadily towards improving mechanisms for the implementation of the 1980 and 1996 Conventions in its territory in order to ensure children's rights to maintain personal relations and direct contact with both parents and guarantee the rights of custody and access to a child to be exercised by both parents living in different States in the event of care disputes between them. It appears that the amendments made in this regard in the Russian legislation will 
coordinate the activities of the Ministry of Education and Science of Russia, acting as a central body of the Conventions implementation, and the competent public authorities They will also speed up the examination of applications on the basis of these international treaties, and thus increase the level of protection of the rights of children and their parents (or other legal representatives) in the territory of the Russian Federation, and strengthen the legal mechanisms of interaction between states in matters regulated by the above mentioned international instruments.

\section{Conclusion}

In this regard, the outreach activities, both among the public and the relevant government authorities, become of great importance. It appears that special attention should be paid to providing professional training to Russian judges and employees of the Federal Bailiff Service, as well as family law experts with the participation of the academic community (Franklin, 2001; Fortin, 2003).

In any case, in all the described measures taken by the State a particular consideration should be attributed to the principle of ensuring the best interests of the child in accordance to para. 1 of Art. 3 of the UN Convention on the Rights of the Child of 1989, which reads as follows - "a child is entitled to have his/her best interests to be assessed and taken into account as a primary consideration while any action or decision in both public and private sphere are made in his or her regard." (Detrick, 1999; Freeman, 2007).

\section{Acknowledgments}

This article was prepared in frames of grant on methodological support of the application of the 1980 and 1996 Hague Conventions in the Russian Federation awarded by the Ministry of Education of Russian Federation.

\section{References}

Abashidze, A. Kh., Gugnskiy, D. A., Koneva, A. E., \& Solntsev, A. M. (2014). Protection of children in case of disputes on the upbringing of children between parents living in the territory of different States. Bulletin of the People's Friendship University of Russia. Series: legal sciences, 3, 241-249.

Archard, D. (2004). Children: Rights and Childhood. Psychology Press.

Archard, D., \& Macleod, C. M. (2002). The Moral and Political Status of Children. Oxford University Press. http://dx.doi.org/10.1093/0199242682.001.0001

Archard, D., \& Skivenes, M. (2010). Deciding Best Interests: General Principles and the Cases of Norway and the UK. Journal of Children's Services, 5(4), 43-54. http://dx.doi.org/10.5042/jcs.2010.0695

Convention on the Civil Aspects of International Child Abduction of 1980. Retrieved from http://www.hcch.net/ index_en.php?act=conventions.text\&cid $=24$

Detrick, S. (1999). A Commentary on the United Nations Convention on the Rights of the Child. The Hague: Martinus Nijhoff.

Eekelaar, J. (1986). The Emergence of Children's Rights. Oxford Journal of Legal Studies, 6(2), 161-182. http://dx.doi.org/10.1093/ojls/6.2.161

Fass, P. (1997). Kidnapped: Child Abduction in America. Cambridge, MA: Harvard University Press.

Fellmeth, R. C. (2002). Child Rights \& Remedies. Clarity Press.

Fenton-Glynn, C. (2014). Children's Rights in Intercountry Adoption. European Family Law.

Forst, M., \& Blomquist, M. (1992). Missing Children: Rhetoric and Reality. New York, NY: Lexington Books.

Fortin, J. (2003). Children's Rights and the Developing Law. Cambridge University Press.

Franklin, B. (2001). The New Handbook of Children's Rights: Comparative Policy and Practice. Routledge.

Freeman, M. (2007). Article 3: The Best Interests of the Child (pp. 1-74).

Guggenheim, M. (2005). What's Wrong with Children's Rights. Harvard University Press.

Jones, P., \& Walker, G. (2011). Children's Rights in Practice. SAGE Publications Ltd.

King, M., \& Piper, C. (1995). How the Law Thinks of the Child (2nd ed.). Aldershot, UK: Arena.

Pardeck, J. T. (2006). Children's Rights: Policy and Practice. Haworth Social Work Practice Press.

Raymond, B. B. (2007). The Baby Thief: The Untold Story of Georgia Tann, the Baby Seller Who Corrupted Adoption (1st ed.). New York: Union Square Press.

Schepetkova, A. N. (2014). The procedure of performing the functions of the Central Authority under the 1980 
Convention by the Ministry of Education of the Russian Federation. Family and housing law, 2.

Skakun, O. S. (2014). The interest of the child as major criterion for the protection of children in the practice of the European court of human rights. Family and housing law, 2.

Solntsev, A. M., \& Koneva, A. E. (2013). International obligations of the Russian Federation in the area of protection of children's rights in light of activities of international universal and regional human rights control organs. Eurasian law journal, 10, 38-42.

Tobin, J. (2009). Judging the Judges: Are They Adopting the Rights Approach in Matters Involving Children? Melbourne University Law Review, 33(2), 579-625.

Zermatten, J. (2010). The Best Interests of the Child Principle: Literal Analysis and Function. International Journal of Children's Rights, 18(4), 483-499. http://dx.doi.org/10.1163/157181810X537391

\section{Notes}

Note 1. Russian woman Irina Bergset to fight for adoption right over her son in Norway. http://en.itar-tass.com/ world/ 688842

Note 2. Russian Rimma Salonen suspends hunger strike in Finland. http://en.infosud.ru/judicial_news/ 20120116/259586434.html

Note 3. Pavel Astakhov describes verdict against Belenkaya as severe. http://sputniknews.com/voiceofrussia/ 2012_10_30/Pavel-Astakhov-describes-verdict-against-Belenkaya-as-severe/; Mother of kidnapped girl free to return to Russia. http://rt.com/news/mother-of-kidnapped-girl-free-to-return-to-russia/

Note 4. Bulgaria (01.08.2013), Croatia (01.06.2012), Czech Republic (01.06.2012), Estonia (01.12.2011), Finland (01.01.2013), France (01.01.2012), Greece (01.01.2012) Ireland (01.07.2013), Lithuania (01.06.2013), Romania (01.06.2013), Slovakia (01.04.2013), Slovenia (01.01.2013), Spain (01.03.2013).

Note 5. Andorra (08/01/2013), Argentina (01.12.2011), Armenia (01.08.2013), Belarus (05.01.2014), Bosnia and Herzegovina (02/01/2014) Brazil (09/01/2013), Chile (01/10/2013), People's Republic of China (01/02/2014), China (Macau) (01.03.2012), Colombia (01.04.2012), El Salvador (01/08/2013), Israel (01.03.2012), Japan (01/04/2014), Mexico (1/11/2013), New Zealand (01.02.2012), Nicaragua (09/01/2013), Paraguay (04/01/2014), the Republic of Moldova (01.01.2014), Serbia (01.06.2013), Seychelles (01.07.2013) Ukraine (01.06.2012), Uzbekistan (01.03.2012).

Note 6. The other key novelty is the determination of the courts (one court in each Federal District) who are competent to receive and consider applications for return of the child or effective exercise of rights of access. Application for return of the child or effective exercise of rights of access is submitted to the Tverskoy district court of the city of Moscow if the whereabouts of the child are on territory of Central Federal District, in the Dzerzhinsky district court of the city of St. Petersburg (North-West Federal District), to the Pervomayskiy district court of the city of Rostov-on-Don (Southern Federal District), in Pyatigorsk municipal court (North Caucasus Federal District), to the Kanavinskiy district court of the city of Nizhny Novgorod (Privolzhsky Federal District), to the Zheleznodorozhny district court of the city of Yekaterinburg (Ural Federal District), to the central district court of the city of Novosibirsk (Siberian Federal District), to the central district court of the city of Khabarovsk (Far Eastern Federal District). The relevant courts in the Republic of Crimea and Sevastopol will be determined later.

Note 7. Furthermore, under Art. 244.15 of the Civil Procedure Code of the Russian Federation "return proceedings or the proceedings for rights of access are heard by the court within a period not exceeding forty-two days from the date of acceptance of the application by the court."

\section{Copyrights}

Copyright for this article is retained by the author(s), with first publication rights granted to the journal.

This is an open-access article distributed under the terms and conditions of the Creative Commons Attribution license (http://creativecommons.org/licenses/by/3.0/). 